\title{
Acquired unilateral rubella retinopathy in adult
}

This article was published in the following Dove Press journal:

Clinical Ophthalmology

15 December 2010

Number of times this article has been viewed

\section{Nadyr Damasceno' \\ Eduardo Damasceno' \\ Eduardo Souza ${ }^{2}$ \\ 'Department of Ophthalmology, Universidade Federal Fluminense, Niterói, RJ, Brazil; ${ }^{2}$ Department of Ophthalmology, Universidade Federal of São Paulo, SP, Brazil}

Correspondence: Eduardo F Damasceno Universidade Federal Fluminense, Faculdade de Medicina, Oftalmologia, Rua Marques do Paraná 303, Niterói, RJ, Brazil

Tel +552 I 25687728

$\mathrm{Fax}+552125687728$

Email eduardodamasceno@vm.uff.br
Abstract: The authors report an uncommon case of unilateral rubella retinopathy in an adult patient, described for the first time in medical literature. A 28-year-old healthy white man acquired a case of vasculitis and retinitis on his right eye with sudden vision loss, preceded by an acute viral disease (best correct visual acuity was 20/200). Serology examinations on several viral diseases reveled positive signs to rubella. The treatment was based on corticoids therapy due to macular commitment with final visual acuity of 20/60. Serology concluded rubella etiology, with positive levels in the acute initial stage of viral infection, even during viral retinopathy.

Keywords: viral retinopathy, acquired rubella, uveitis, case report

\section{Introduction}

Rubella virus is a member of the family Toga viridiae and is only found in humans; there is no known animal reservoir. It is usually a benign febrile exanthema, but the congenital chronic fetal infection may cause malformations: systemic and ocular. Adults are more likely to experience a prodromal phase with malaise, low-grade fever, headache, and conjunctivitis. ${ }^{1-3}$

\section{Case report}

A 28-year-old healthy white man presented with unilateral sudden loss of vision preceded by a flu-like illness. His past medical history was unremarkable. Visual acuity was 20/200 in the right eye and 20/20 in the left eye. There was an afferent pupillary defect in the right eye. Biomicroscopic examination revealed fine keratic precipitates, trace anterior chamber cells, and 1+ anterior vitreous cells in the right eye. Examination of the left eye was normal. Intraocular pressure was $12 \mathrm{mmHg}$ in both eyes. Fundus examination of the right eye showed a mild vitreitis and posterior segment signs of a resolving neuroretinitis, characterized by diffuse retinal edema (macular star), retinal vasculitis, and mild papillitis (Figure 1). The left eye fundus was unremarkable. Fluorescein angiogram confirmed these inflammatory signs in the right eye (Figure 1). Further workup for human immunodeficiency (HIV), venereal disease research laboratory (VDRL), cytomegalovirus (CMV), toxoplasmosis, tuberculosis, and herpes had negative results. A high erythrocyte sedimentation rate (ESR) $(70 \mathrm{~mm} / \mathrm{h})$ and white blood cell (WBC) count (12200 cells $/ \mathrm{mm}^{3}$ ) associated with positive significant level for rubella (IgG $346 \mathrm{UI} / \mathrm{mL}$ and $\operatorname{IgM} 0.8 \mathrm{UI} / \mathrm{mL}$ ) made possible the initial suspicion of unilateral rubella retinopathy in this case. This became reinforced by the "salt and 


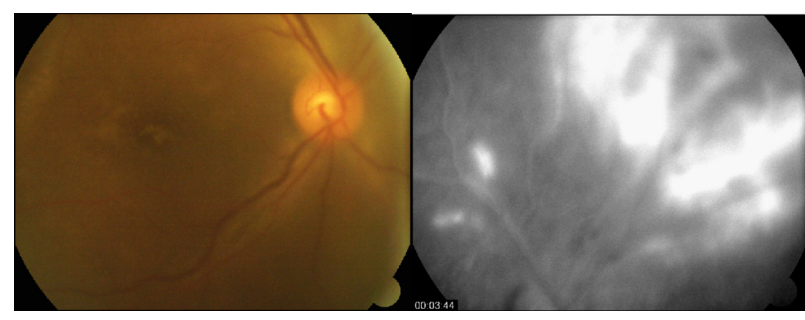

Figure I A) Color photograph of eye fundus before systemic steroid therapy B) fluorescein angiography - late phase - vasculitis as peripheric lesion.

pepper" fundus appearance of his right eye after two months of initial treatment with prednisone (60 $\mathrm{mg}$ for 10 days). His final visual acuity was 20/60 in this eye (Figure 2).

Results analysis also revealed toxoplasma serology $\operatorname{IgG} 14.2 \mathrm{UI} / \mathrm{mL}$ and $\operatorname{IgM} 0.15 \mathrm{UI} / \mathrm{mL}$. The other exams were normal. A progressive decrease of rubella serology levels (IgG 264.6 UI/mL after one month) and a final level of $184 \mathrm{UI} / \mathrm{mL}$ in the second month of follow-up was noticed.

\section{Discussion}

Rubella is only found in humans and is transmitted via the respiratory tract. It is generally a mild disease in children, but may be more severe in adults. It has a maculopapular rash and adults are more likely to experience a prodromal phase with malaise and low-grade fever. ${ }^{4}$

Rubella is indistinguishable clinically from other infections that present with rash, such as parvovirus B19, measles, human herpesvirus 6 and 7, enterovirus, and group A streptococcus infections. ${ }^{1}$ In tropical countries, like Brazil, dengue should also be considered.

In this case, the patient was diagnosed as having rubella. Among all the exams solicited, only the serology for rubella

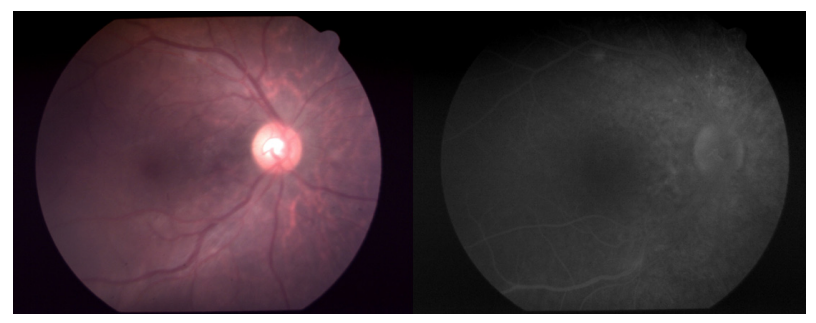

Figure 2 A) Color photograph of eye fundus after systemic steroid therapy B) fluorescein angiography - late phase - vasculitis evolving to salt and pepper lesion.
(IgG $346 \mathrm{UI}$ ) and for toxoplasmosis (IgG 14.2 UI) were positive and the other exams were negative.

The ocular complications of the rubella must be differentiated from other causes of vasculitis and retinitis. Diagnostic tests to rule out other causes of vasculitis and retinitis were solicited: VDRL, serology for CMV, toxoplasmosis antibodies, HIV, herpes, ESR, chest radiographs, rheumatologic tests, white blood cells count, and tuberculin test. ${ }^{5}$ Salt and pepper pigmentary disturbance is a most common ocular complication in congenital rubella but it is not common in adult acquired rubella. ${ }^{6}$

Because the antibody level to rubella was high during the subacute stage and decreased within two months, we believe this patient had unilateral rubella retinitis, a rare condition not described in adults. We believe this case has several important medical implications to be discussed. First, it demonstrates the necessity to correlate inflammatory ocular findings with previous (or concomitant) systemic diseases, especially viral. Second, it may confirm the possibility of rarely described cases of congenital unilateral rubella retinopathy. Third, it clearly shows the pathogenesis of a salt and pepper retinal appearance originating from a viral-modified previously normal retinal tissue.

\section{Disclosure}

No conflicts of interest were declared in relation to this paper.

\section{References}

1. Best J. Rubella. Sem Fetal Neonatal Med. 2007;12(3):182-192.

2. Heggie A, Robbins F. Natural rubella acquired after birth - clinical features and complications. Am J Dis Child. 1969;118(1):12-17.

3. Cutts FT, Robertson SE, Diaz-Ortega JL, Samuel R. Control of rubella and congenital rubella syndrome (CRS) in developing countries, Part 1: Burden of disease from CRS. Bull World Health Organ. 1997;75(1):55-68.

4. de Visser L, Braakenburg A, Rothova A, de Boer JH. Rubella virus associated uveitis: clinical manifestations and visual prognosis. Am JOphthalmol. 2008;146:292-297.

5. Schuil J, van de Putte EM, Zwaan CM, Koole FD, Meire FM. Retinopathy following measles, mumps, and rubella vaccination in an immunoincompetent girl. Int Ophthalmol. 1998;22:345-347.

6. Khurana R, Sadda S. Images in clinical medicine. Salt-and-pepper retinopathy of rubella. $N$ Engl J Med. 2006;355:499.
Clinical Ophthalmology

\section{Publish your work in this journal}

Clinical Ophthalmology is an international, peer-reviewed journal covering all subspecialties within ophthalmology. Key topics include: Optometry; Visual science; Pharmacology and drug therapy in eye diseases; Basic Sciences; Primary and Secondary eye care; Patient Safety and Quality of Care Improvements. This journal is indexed on Submit your manuscript here: http://www.dovepress.com/clinical-ophthalmology-journal

\section{Dovepress}

PubMed Central and CAS, and is the official journal of The Society of Clinical Ophthalmology (SCO). The manuscript management system is completely online and includes a very quick and fair peer-review system, which is all easy to use. Visit http://www.dovepress.com/testimonials.php to read real quotes from published authors. 